http://dx.doi.org/10.12775/szhf.2014.038

\title{
Ewa Domańska, Historia egzystencjalna. Krytyczne studium narratywizmu i humanistyki zaangażowanej, Wydawnictwo Naukowe PWN, Warszawa 2012, ss. 223
}

Autorka Historii egzystencjalnej jest profesorem Uniwersytetu im. Adama Mickiewicza, pracuje w tamtejszym Instytucie Historii, a oprócz tego jest także visiting associated profesor w Department of Antropology, Stanford University w Stanach Zjednoczonych. Badaczka zajmuje się głównie współczesną teorią i historią historiografii. Pierwsze wrażenie, które można odnieść sięgając po omawianą książkę jest takie, że może być ona kolejną próbą uporządkowania dorobku myśli egzystencjalnej, kolejną falą postmodernistycznych ucieleśnień odwołujących się do aspektów myśli egzystencjalnej, psychologicznej i literaturoznawczej. Wydawać by się mogło, że będzie to próba sporządzenia synkretycznego naukowego wykładu ze szczyptą krytycyzmu. Nic bardziej mylnego.

Publikacja składa się z siedmiu rozdziałów. Pierwszy odnosi się do kwestii związanej z narratywizmem oraz opisem fenomenu poetyki pisarstwa historycznego. Drugi związany jest z estetycznym wymiarem narratywizmu - czyli reprezentacją i doświadczeniem historycznym. Następny rozdział oscyluje wokół problematyki faktu historycznego, a co za tym idzie - ontologicznego ujęcia tych faktów. Czwarty rozdział skupia się na toposie tradycyjnego historyka, wielości oraz wieloznaczności historii, a także na samej filozofii dziejów. Rozdział zatytułowany: „Epistemologia bez niewinności” ukazuje, w jaki sposób możemy poznawczo odnieść się do teorii historycznej oraz kładzie szczególny nacisk na budowanie mocnego podmiotu, co będzie wyjaśnione poniżej w tym artykule. Rozdział szósty, pt. „Forget Foucault” odnosi się do dyskusji dotyczącej koncepcji wiedzy - władzy. W ostatnim, dziewiątym, 
rozdziale zostało poruszone zagadnienie związane z metodologią praktyczną, która ma pomóc budować teorie historyczne.

Zanim jednak przejdziemy do analizy ciekawych aspektów książki Ewy Domańskiej, należy razem z badaczką zadać pytanie, czym jest historia egzystencjalna sensu stricto, której założenia w swej pracy stara się przedstawić autorka? Należy podejść do tego typu rozważań intelektualnych w sposób wielowymiarowy, albowiem publikacja ta czerpie $\mathrm{z}$ wielu nauk humanistycznych, takich jak: filozofia, socjologia, antropologia, ekofilozofia a także gender studies. Faktem jest, że książka nie powstałaby, gdyby ponowocześnie nie wystąpił na polu naukowym kryzys poznawczy i normatywny. Bycie zaangażowanym w dogłębne analizowanie procesów dziejowych z punktu widzenia metodologii i historiozofii jest - jak się zdaje - zadaniem nie tylko trudnym, ale i kontrowersyjnym. Poznańska badaczka wprowadza nas w rzeczywistość interdyscyplinarnej kreacji humanistycznej, przepojonej mentalnym dyskursem. Jest to związane z przeformułowaniem obecnie panującego paradygmatu epistemologicznego, etycznego i kulturowego. Transhumanistyka dąży do ulepszenia jednostek ludzkich dzięki inżynierii genetycznej, psychofarmakologii, czy nanotechnologii.

Pretensjonalna postawa naukowców, którzy dążą do znalezienia jednej, obiektywnej, a zarazem niepodważalnej prawdy, zostaje tutaj pozbawiona podstaw. Czytając publikację Ewy Domańskiej, zrazu nasuwa się spostrzeżenie, że relatywistyczny punkt wyjścia daje obecnie możliwość prowadzenia kulturowego dialogu oraz poszerzenia horyzontu poznawczego, co jest równoznaczne z niezgodą na panujące współcześnie trendy gnuśności i infantylizacji celów naukowych. Widocznie jest to głównie w przetwarzaniu informacji z pomocą przestrzeni wirtualnej. Elias Aboujaounde - współczesny stanfordzki psychiatra i autor fenomenalnej publikacji Wirtualna osobowość naszych czasów. Mroczna strona e-osobowści podkreśla, że poszukując $\mathrm{w}$ Internecie cząstkowych informacji, przestaliśmy być nurkami w morzu słów, a staliśmy się prującymi po powierzchni początkującymi windsurfingowcami ${ }^{1}$. Cóż to jednak znaczy? Badacz zwraca szczególną uwagę na fakt, że cyberprzestrzeń w coraz większym stopniu zwalnia człowieka z myślenia, przez co tworzone są jednostki sterowane informacyjną papką, bez zdolności do krytycznej analizy internetowych zasobów². Stąd też, gubiąc się w gąsz-

${ }^{1}$ E. Aboujaoude, Wirtualna osobowość naszych czasów. Mroczna strona e-osobowości, Kraków 2012, s. 186.

${ }^{2}$ Tamże, s. 200. 
czu informacji, stajemy się przede wszystkim myśliwymi, czyhającymi, czy pojawi się jakaś łatwa ofiara, którą nasz intelekt będzie mógł bezrefleksyjnie przemielić3.

Niewątpliwie tocząca się obecnie dyskusja dotycząca zagadnień posthumanizmu, zakwestionowania prowadzenia „wielkich narracji”, a także ogromny nacisk kładziony na dopełnienie myślenia w kategoriach mocnego, a nie słabego podmiotu, doprowadziły do przewartościowania esencjalnego spojrzenia na świat. Autorka Historii niekonwencjonalnych ${ }^{4}$ zaznacza, że silna podmiotowość powinna być hybrydyczna. Gdy spotykamy się z odmiennym dyskursem teoretycznym bądź człowiekiem, pozwala to na „unieważnienie naszej rzeczywistości i przemieszczenie naszego stanowiska, podmiotu, ra-

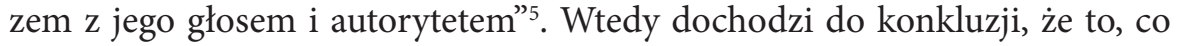
mieliśmy za obiektywne i naturalne, jawi się jako prowincjonalne i dziejowe ${ }^{6}$. Postmodernistyczny świat próbuje zerwać z pojęciem prawdy rozumianej klasycznie. Amerykański myśliciel Rorty wielokrotnie podkreślał, że zagraża ona demokracji i ma cechy totalitarne, co oczywiście może doprowadzić do monopolizacji tego terminu. Filozof francuski - Jacques Derrida - podkreślał, że wszelkie prawdy podlegają dekonstrukcji w ciągu intertekstualnym. Myśliciele wpleceni w krąg postmodernistyczny uważają, że prawda nie jest odkrywana, lecz wytwarzana. Do prawdy dochodzi się wówczas, gdy na drodze sporów osiąga się poznawcze porozumienie. Jest ona zmienna, sytuacyjna w stosunku do określonego dyskursu. We współczesnej nauce mamy do czynienia z wielością dyskursów, dlatego też należy zaakceptować wielość prawd $^{7}$.

Ewa Domańska wielokrotnie w swej rozprawie zwraca uwagę na kategorię podmiotu performatywnego - to taki podmiot, który nie przygląda się egzystencjalnemu widowisku, lecz jest sprawcą, kreatorem, inicjatorem kulturowego przedsięwzięcia. Koegzystuje $\mathrm{z}$ innymi bytami, również bytami nie-ludzkimi, dzięki czemu rozwija się dialog z naukami biologicznymi, co z kolei zapoczątkowuje nowy nurt zwany biohumanistyką. Ewa Domańska nawiązuje do myśli Bruno Latoura, który stworzył projekt socjologii krytycz-

\footnotetext{
${ }^{3}$ Tamże, s. 182.

${ }^{4}$ Zob. E. Domańska, Historie niekonwencjonalne. Refleksja o przeszłości w nowej humanistyce, Poznań 2006.

${ }^{5}$ Z. Melosik, T. Szkudlarek, Kultura, tożsamość i edukacja - migotanie znaczeń, Kraków 1998, s. 28.

6 Tamże.

${ }^{7}$ A. Szahaj, Postmodernizm w kulturze współczesnej, Bydgoszcz 2001, s. 27.
} 
nej. Nie chodzi tutaj jednak o naukę w sensie społecznym jako socjology od the social. Nacisk jest kładziony przez niego na naukę, która będzie potrafiła znaleźć powiązania między różnymi gatunkami nauki. Proponuje, aby używać terminu „kolektyw” zamiast terminu „społeczność”, albowiem wtedy mogłoby dojść do koegzystencji bytów nie-ludzkich z ludzkimi ${ }^{8}$. Latour odwołuje się do metafory teatru, a byty nie-ludzkie zostają przez niego określone mianem aktorów. Nigdy nie wiadomo, kto jest podmiotem sprawczym i jak działa, podobnie jak w przypadku aktora, który nie gra sam na scenie. Jest on częścią działających w sieci podmiotów sprawczych/performatywnych ${ }^{9}$. Słaba podmiotowość cechuje się wycofaniem, biernością, stagnacją poznawczą. Wobec tego owo słabe "ja” najlepiej się czuje, otoczone troską i opieką innych:

Jestem słabym podmiotem, bo taki/taka jestem, wygodnie nim być szczególnie, jeżeli otoczenie pozwala mi na to; poczuwa się do ochrony, podejmuje za mnie decyzje i skłonne jest wybaczać ewentualne błędy wynikające z owej kruchości. Warto podkreślić, iż w ten sposób otoczenie kastruje podmiotowość w imię troski, w której tle często stoi kontrola ${ }^{10}$.

Ewa Domańska oprócz nawiązania do mocnego podmiotu sprawczego odnosi się również do tego, że obecnie w nauce został zakwestionowany antropocentryczny punkt widzenia. Zastąpił go „biosferyczny egalitaryzm”, dlatego tak często mówi się dziś o upadku paradygmatu antropocentrycznego. Badaczka stara się uzmysłowić czytelnikom, że transgresje intelektualne powinny dążyć do zniesienia blokad krępujących pokrewne dziedziny wiedzy.

Zgadzam się z autorką, która w szóstym rozdziale swej książki, noszącym tytuł „Forget Foucault!” podkreśla, że zostaliśmy namaszczeni przez „efekt Foucaulta”. Cóż to jednak znaczy? Nic innego, jak to, że:

${ }^{8}$ E. Domańska, „Zwrot performatywny” we współczesnej humanistyce, http://www.staff.amu. edu.pl/ ewa/Domanska,\%20Zwrot\%20performatywny\%20we\%20wspolczesnej\%20humanistyce.pdf [dostęp z dnia: 10.02.2014], s. 68.

9 Tamże oraz B. Latour, Prolog w formie dialogu pomiędzy studentami a (cokolwiek) sokratycznym Profesorem, przeł. K. Arbiszewski i in. „Teksty Drugie” 2007, nr 1/2.

${ }^{10}$ E. Domańska, Historia egzystencjalna. Krytyczne studium narratywizmu i humanistyki zaangażowanej, Warszawa 2012, s. 140. 
Jest to szereg niesprzyjających i obezwładniających skutków nadinterpretowanej i zaadoptowanej do realiów amerykańskich deterministycznej i totalizującej wizji władzy oraz koncepcji relacji wiedzy - władzy ${ }^{11}$.

Oczywiście współcześnie możemy również mówić o „efekcie Freuda” i jego implikacjach psychohistorycznych. Freudowska psychoanaliza (obecnie mamy do czynienia $\mathrm{z}$ psychodynamicznym nurtem $\mathrm{w}$ psychologii) zanegowała racjonalność człowieka na rzecz sfery irracjonalnej. Sfera nieświadoma kieruje się własnymi zasadami, wpływając na działania w sferze świadomej - czyli w obrębie jaźni - ego ${ }^{12}$. Dlatego też niektórzy badacze, biorąc pod uwagę metodę analityczną oraz dokonania tej wiedeńskiej szkoły terapeutycznej, korzystają z wypracowanej terminologii i aparatu pojęciowego, by zrekonstruować działania ludzi oraz motywy kierujące nimi w przeszłości przy badaniu danej zbiorowości ${ }^{13}$.

Jednakże absolutyzowanie jednej teorii, próba naniesienia na rzeczywistość wyłącznie jednej z wielu siatek pojęciowych, rodzi redukcjonizm poznawczy, co zdaniem Ewy Domańskiej może doprowadzić do regresu intelektualno-etycznego ${ }^{14}$. Książka poznańskiej badaczki nie zdradza jednak zgorszenia i rozczarowania współczesnym stanem badań ani postawą samych badaczy, tj. klasycznych historyków.

Kwestią coraz częściej poruszaną na polu nauk historycznych jest przede wszystkim rola, jaką powinna spełniać metodologia praktyczna, wyłączając metodologię teoretyczną, wyabstrahowaną od problemów dnia codziennego. Ewa Domańska w swym artykule, pt. Jakiej metodologii potrzebuje wspótczesna humanistyka? stwierdza, że obecnej nauce potrzebny jest model performacyjny, w którym istotny jest utylitarny charakter wytworzonej wiedzy. Zaznacza, że współczesna humanistyka powinna być rodzajem wiedzy performatywnej. To znaczy, że wiedza ta powinna dostarczać człowiekowi możliwości kreowania własnej wizji rzeczywistości, a wdrożenie jej w życie pozwoli na kreatywne dopasowanie się do środowiska nie tylko naturalnego, ale również społeczno-kulturowego. Autorka publikacji stwierdza, że nauce potrzebna jest metodologia praktyczna, czyli taka „która powstaje na bazie

\footnotetext{
11 Tamże, s. 156.

${ }^{12}$ D. Sikorski, Miejsce i rola źródeł w psychohistorii, „Acta Universitatis Wratislaviensis”, nr 2675, Historia, CLXX, Wrocław 2004, s. 73.

${ }^{13}$ T. Pawelec, Psychohistoria a psychoanaliza (z problematyki wzajemnych relacji), [w:] Historia, metodologia, współczesność, „Res Historica” 6, red. J. Pomorski, Lublin 1998, s. 117-133.

${ }^{14}$ E. Domańska, Historia egzystencjalna, s. 180.
} 
analiz danych i na ich potrzeby jest tworzona. Chodzi zatem o metodologię preskryptywną, ale nie normatywną podążającą w innym kierunku niż metodologia wyabstrahowana od badań historycznych, która skupia się na analizach efektów pracy historyka i czynnościach poznawczych, które tej pracy towarzyszą"15. Chodzi tutaj o metodologię teorii dającą naukowcom narzędzia, dzięki którym będą oni potrafili zbudować teorię oddolną. „Metodologię będę tutaj rozumiała w sposób uproszczony jako zespół praktyk badawczych, tj. procedur i strategii, które wskazują j a k budować teorie. Pojęciem teorii posługuję się tutaj $\mathrm{w}$ sensie szerokim jako zbiorem pewnych pojęć i konstrukcji wyjaśniających, które pozwalają na konceptualizację i interpretację badanych zjawisk" ${ }^{16}$. Pytanie, czy metodologia praktyczna jest praktyką reinterpretowania źródeł historycznych, co jest związane z hermeneutyką? Profesor Domańska zwraca szczególną uwagę w swej publikacji, że metoda pragmatyczna stanowi przedsionek naszego rozumienia historycznego. Dlatego też nad jej pracami unosi się filozoficzna aura, która domaga się dopełnienia w postaci wiedzy z, jak już wcześniej wspomniałam, szeroko rozumianej współczesnej humanistyki.

Istotną kategorią przywołaną przez poznańską badaczkę jest dowartościowanie idei mocnego podmiotu (sprawczego). W tym miejscu autorka Historii egzystencjalnej powołuje się na Stanleya Fisha - zadeklarowanego antyfundamentalistę, który stanowczo podkreśla, że w szeroko pojętej posthumanistyce nie należy pozbawiać jednostek wrodzonego poczucia bezpieczeństwa, fundamentów i konstrukcji społecznych konstytuujących ich egzystencję. Warto wskazać na ich ewolucję, w której chodzi raczej o

kontekstualizację i historyzację podmiotu; o podkreślenie, że nie ma fundamentów, esencji czy wartości niezależnych od kontekstu; one istnieją, ale są lokalne, historyczne, przygodne i zmienne ${ }^{17}$.

Jak już zaznaczyłam na początku artykułu, Ewa Domańska odwołuje się do poglądów Richarda Rorty’ego, z tym, że wiedza ludzka (rozumiana jako poznanie - episteme) ma charakter przygodny. Amerykański neopragmatysta dowodził, że prawda nie ma celu samego w sobie, nie jest norką, do której dążymy, albowiem ta pisana przez duże „P” nie istnieje. „Powinniśmy przy-

${ }^{15}$ E. Domańska, Jakiej metodologii potrzebuje współczesna humanistyka? „Teksty Drugie”, 2010, nr 1-2, s. 45-55.

${ }^{16}$ Tamże.

${ }^{17}$ E. Domańska, op. cit., s. 135. 
jąć epistemiczne, a tym samym elimininatywistyczne podejście do pojęcia prawdy i pod pojęciem prawdy przez małe „p" rozumieć jedynie pojęcie uzasadnienia"18. Ten postmodernistyczny filozof miał niebagatelny wpływ na książkę profesor Domańskiej, czego dowodem może być sformułowana przez niego myśl dotycząca postrzegania kultury jako pewnej ciągłości:

Historycystyczna i nominalistyczna kultura, jaką sobie wyobrażam, poprzestawałaby na narracjach, które wiążą teraźniejszość z jednej strony z przeszłością, $\mathrm{z}$ drugiej zaś - $\mathrm{z}$ utopiami przyszłości ${ }^{19}$.

Ewa Domańska często w swych publikacjach stwierdza, że zagadnienie „Zwrotu performatywnego" winno interesować współczesnych badaczy humanistycznych ${ }^{20}$. Zwrot ten jest nierozerwalnie związany z kategorią ludzkiej sprawczości. Nasze posthumanistyczne zakotwiczenie w świecie jest związane $\mathrm{z}$ egzekwowaniem tego, co ludzkie nie jest ${ }^{21}$. Ewa Domańska niejednokrotnie zaznaczała, że potrzebujemy zmiany humanistycznego paradygmatu. Humanistyka powinna też kreować wzorce, które będą pomagały ochraniać i przedłużać trwanie gatunku. Autorka Historii egzystencjalnej podkreśla, że to głównie współczesne naukowe problemy łączą badaczy, a nie spory ideologiczne i teoretyczne ${ }^{22}$. Kwestie te często są związane z szeroko pojętą ochroną życia, stąd narodziny takich nauk, jak: bioetyka, ekofilozofia, aksjomedycyna. Oczywiste wydaje się, że nie chodzi tutaj o pozbawienie człowieka mocy decyzyjnej, lecz o odebranie mu możliwości bycia centrycznym i narzucającym podmiotem. Dochodzimy tutaj do zerwania z protagorejską formułą, która stwierdzała, że człowiek jest miarą wszechrzeczy. Istniejących, że istnieją, nie istniejących, że nie istnieją ${ }^{23}$. Cytując Domańską:

\footnotetext{
${ }^{18}$ B. Orlewski, Kontekstualizm epistemologiczny a neopragmatyzm, „Słupskie Studia Filozoficzne", 2010, nr 9, s. 124.

${ }^{19}$ R. Rorty, Przygodność, ironia i solidarność, Warszawa 2009, s. 18.

${ }^{20}$ Zob. E. Domańska, Jakiej metodologii potrzebuje współczesna humanistyka? „Teksty Drugie”, nr 1-2, 2010, s. 45-55.

${ }_{21}$ „Warto w tym miejscu zwrócić uwagę, że z punktu widzenia logiki ludzkie/nie-ludzkie nie stanowi przykładu binarnej opozycji. Opozycją wobec pojęcia człowiek może być zwierzę czy rzecz; określenie „nieludzkie” jest natomiast jego zaprzeczeniem”. E. Domańska, Humanistyka nie - antropocentryczna a studia nad rzeczami, „Kultura Współczesna”, 2008, nr 3, s. 9-21.

22 Tamże, s. 10.

${ }^{23}$ Tamże.
} 
Prowadzone w ramach nowej humanistyki dyskusje na temat tożsamości, inności oraz wykluczenia coraz częściej obejmują byty nie-ludzkie: zwierzęta, rośliny i rzeczy. Inny to już nie tylko ktoś, kto różni się od nas - innych ludzi - ze względu na rasę, płeć, klasę lub opcję seksualną czy religijną, lecz także ktoś, a może przede wszystkim ten/ta/to, kto różni się od nas gatunkowo i/oraz organicznie (w sensie na przykład bycia nie-organicznym) ${ }^{24}$.

Dlatego też ogromny nacisk został położony na działanie w sferze praxis: „Świat nie jest już postrzegany jako księga, którą się czyta, lecz jako performance, w którym się uczestniczy"25. Dlatego też mamy tutaj do czynienia $\mathrm{z}$ manifestacją przejścia z nadmiernego kontemplowania, namysłu, teoretyzowania do kategorii „dziania się” i przedmiotu zmiany. Bycie nieprzerwanie w ruchu, reinterpretowanie zastanych faktów, teraźniejsze zakotwiczenie się w doświadczeniu, jest kwestią wiążącą współczesną humanistykę.

Warte podkreślenia jest, że Ewa Domańska zdaje sobie sprawę z tego, iż teoretyk historii powinien również zdobywać wiedzę z zakresu psychologii. Nie tylko odwoływanie się do psychoanalizy Freudowskiej i Lacanowskiej, ale także odniesienia do psychologii egzystencjalnej, dają horyzontalny ogląd dążeń ludzkich. Czytamy:

I dopiero w oddaniu się jakiejś sprawie kształtujemy własną osobę. Nie przez kontemplowanie siebie ani przez samouwielbienie, nie przez krążenie myślami wokół naszego lęku uwalniamy się od tego lęku - lecz przez poświęcenie, ofiarę $\mathrm{z}$ siebie i oddanie się sprawie godnej takiego oddani ${ }^{26}$.

Tomasz Pawelec w swym artykule pt. Historyk jako społeczny psychoterapeuta (etyczne przesłanki pisarstwa psychohistorycznego) podkreśla, że współczesne badania historyczne winny czerpać ze spuścizny psychoanalitycznej. $\mathrm{Z}$ jednej strony badacze powinni wyróżnić poziom ontologiczny, czyli fundament poznania człowieka i jego funkcjonowania w świecie oraz poziom metodologiczny. Dzięki psychoanalitycznej metodologii możliwe jest zastosowanie narzędzi psychologii głębi do analizy procesów z przeszłości ${ }^{27}$. Historycy interesujący się psychologią, zwracają szczególną uwagę na działania sfery irracjonalnej oraz ukazują terapeutyczne, uzdrawiające walory tej na-

\footnotetext{
${ }^{24}$ Tamże.

${ }^{25}$ R. Schechner, Performance Studies. An Introduction, Routledge, London 2002, s. 21.

${ }^{26}$ V. Frankl, Psychoterapia dla każdego, Warszawa 1978, s. 53.

${ }^{27}$ T. Pawelec, Historyk jako społeczny psychoterapeuta (etyczne przesłanki pisarstwa psychohistorycznego), „Kultura i Historia”, 2002, nr 3, s. 65.
} 
uki. Głównie chodzi tutaj o wykrycie ogromnych pokładów siły niszczycielskiej - destrudo - w przeszłościowych stosunkach społecznych. Domańska oraz Pawelec sugerują, że badanie zaangażowane, czyli psychoterapeutyzowanie jednostek i zbiorowości ma znaczący sens naukowy ${ }^{28}$. Freud w książce Kultura jako źródło cierpień zapytywał między innymi:

Skoro bowiem rozwój kultury wykazuje tak daleko idące podobieństwo z procesem rozwoju indywiduum, [...] to czyż nie wolno nam postawić diagnozy, że niektóre kultury - epoki w dziejach kultury czy też być może cała ludzkość stały się „neurotyczne” pod wpływem dążeń kulturowych? [...] Jeśli zaś chodzi o terapeutyczne zastosowanie tego wglądu, to co nam przyjdzie po nawet najtrafniejszej diagnozie nerwicy społecznej, skoro nikt nie ma aż tak wielkiego autorytetu, by mógł narzucić terapię całej zbiorowości? Mimo wszystkich tych utrudnień możemy jednak spodziewać się, że pewnego dnia ktoś podejmie wyzwanie opracowania takiej patologii wspólnot kulturowych ${ }^{29}$.

Dlatego też częstokroć psychologia oraz psychoterapia typu psychoanalitycznego powinna czerpać "garściami” od swych starszych filozoficznych i historycznych braci, którzy skupiali całą swoją wolę na tajemnicy ludzkiego bytu oraz jego intencjonalnej naturze, dzięki której może on wyjść z zaścianka wewnętrznych blokad i mechanizmów obronnych.

Odnosząc się do warsztatu badań historyka, Ewa Domańska podkreśla, że naukom historycznym potrzebny jest nowy metajęzyk, który nie może zostać stworzony bez odwoływania się do starych pojęć i tradycji metodologicznej. Dzięki odwołaniu się do wcześniejszej terminologii, naukowiec może bez problemu generować nowe problemy badawcze, konstruując przy tym nowe definicje i znaczenia. Stąd też nawoływanie Domańskiej o przywrócenie pozytywnego statusu postawie moralnej badaczy i zwrócenie się ku etyce cnoty $^{30}$. Obecnie krystalizująca się etyka cnót związana jest $\mathrm{z}$ moralną i poznawczą działalnością samego podmiotu. Za fundamentalne pytanie uznaje się tutaj: „jakim powinienem być człowiekiem?” i ono właśnie zostało tutaj przeciwstawione pytaniu etyk deontycznych (imperatywy kantowskie i utylitaryzm) „co powinienem czynić"? ${ }^{31}$ Etycy cnót stoją na stanowisku, że nie należy poddawać analizie pod kątem moralnym wartości abstrakcyjnych,

\footnotetext{
${ }^{28}$ Tamże.

${ }^{29}$ S. Freud, Kultura jako źródło cierpień, [w:] tenże, Dzieła, t. 4, s. 226.

${ }^{30}$ E. Domańska, Historia egzystencjalna, s. 176.

${ }^{31}$ N. Szutta, Status wspótczesnej etyki cnót, „Diametros”, 2004, nr 1, s. 71.
} 
lecz powinniśmy skupić się na odpowiednim moralnym wychowaniu podmiotu moralnego. Chodzi tutaj głównie o wykształcenie cnót, czyli danych dyspozycji moralnych oraz wykształcenie dobrych motywacji, intencji i postaw moralnych. Filozofowie i antropolodzy kulturowi optujący za współczesną etyką cnót podkreślają, że to jednostka jest sprawcą czynów, dlatego też możemy je rozpatrywać $w$ kategorii etycznej ${ }^{32}$. Jeden $z$ najbardziej znanych przedstawicieli etyki cnót Alasdair MacIntyre (skrajny przeciwnik kantowskiego absolutyzmu) podkreśla, że każdy człowiek rodzi się w stanie potencjalności, a celem jego życia jest każdorazowa moralna aktualizacja. Moralność zdaniem filozofa, głównie określone cnoty, pełnią funkcję instrumentów, które mają za zadanie doprowadzić podmiot do stanu moralnej refleksji ${ }^{33}$. Obecnie panującą etykę cnót nazywa się również etyką charakteru i jest ona antagonizowana $\mathrm{z}$ etyką zasad (etyka uniwersalizacji i prawa powszechnego u Kanta oraz zasada użyteczności u utylitarystów) ${ }^{34}$. Jedynymi pryncypiami, które akceptują propagatorzy etyki cnót są tak zwane zasady cnoty, przede wszystkim zasada bycia lojalnym, życzliwym czy sprawiedliwym. Zasady te mają charakter skonkretyzowany i nie są abstrakcyjne ${ }^{35}$.

Ostatecznie Ewa Domańska w swej Historii egzystencjalnej zwraca uwagę na zagadnienie epistemologii cnoty. Cytując autorkę:

Od dawna jestem przywiązana do idei (wartości i cnoty). Analizując różnego rodzaju historie niekonwencjonalne, doszłam swego czasu do wniosku, że szczerość nie jest użyteczną kategorią analizy, lecz także staje się pryncypium pracy historyka, ważniejszym od dążenia do prawdy, gdyż jest ona warunkiem jej osiągnięcia. Szczerość intelektualna (intellectual honesty) to zatem cnota i wartość, która - obok rzetelności, sumienności odwagi intelektualnej, otwartości krytyczności, umiarkowania i odpowiedzialności - staje się dla historyka po prostu obowiązkiem.

Jak widzimy, autorka odwołuje się tutaj do kategorii postaw moralnych ${ }^{36}$. Obecnie mamy do czynienia $\mathrm{z}$ indyferentyzmem etycznym ${ }^{37}$, łamaniem

32 Tamże, s. 72.

${ }_{33}$ A. MacIntyre, Dziedzictwo cnoty. Studium $z$ teorii moralności, przeł. A. Chmielewski, PWN, Warszawa 1996, s. 112-115.

${ }^{34}$ N. Szutta, Status wspótczesnej etyki cnót, „Diametros”, 2004, nr 1, s. 72.

${ }^{35}$ Tamże.

${ }^{36}$ E. Domańska, Historia egzystencjalna, s. 181.

${ }^{37}$ M. Gołaszewska, Hipotetyczna wartość wartości, [w:] Wartości dla życia, red. K. Popielski, KUL, Lublin 2008, s. 92. 
wszelkich zasad moralnych. Chodzi tutaj o występujący postmodernistycznie status pluralizmu aksjologicznego. Zasadniczo, dążenie do pluralizmu etyczno-aksjologicznego wyznacza od strony esencjalnej otwartość, tolerancję, życzliwość i akceptację wobec inności światopoglądowej drugiego człowieka, otwarcie się na świat wartości i aksjosfery ${ }^{38}$.

Etyka materialna Maxa Schelera przestaje być dla ludzi satysfakcjonująca. Fenomenolog ujmuje istotę człowieka w aspekcie wartości etycznych. U Schelera mamy do czynienia $\mathrm{z}$ hierarchią wartości. Na samym dole umieścił on wartości utylitarne (związane $\mathrm{z}$ życiem), następnie mamy hedonistyczne (związane z ludycznym charakterem egzystencji), wyżej witalne (związane z cielesnością), jeszcze wyżej znajdują się wartości duchowe, które filozof wiążę z kulturą i etyką. Na najwyższym poziomie znajdują się wartości absolutne, religijne ${ }^{39}$. Współcześnie do głosu dochodzi kulturowo i sytuacyjnie uwarunkowana etyka cnót, która skupia całą swoją uwagę na sferze działaniowej człowieka bez odnoszenia jego poczynań do niezmiennych Kantowskich prawideł w imię imperatywu kategorycznego i prawa powszechnego ${ }^{40}$. Dlatego też uważam, że publikacja Ewy Domańskiej warta jest przeanalizowania. Prowokujący tytuł i inspirująca treść powodują, że niezależnie od zainteresowań badawczych odbiorcy, zanurzy się on w problematy związane ze współczesną kondycją szeroko pojętej humanistyki.

Aleksandra Kondrat

\footnotetext{
38 Tamże, s. 91.

${ }^{39}$ M. Scheler, O idei człowieka, w: M. Scheler, Pisma z antropologii filozoficznej i teorii wiedzy, PWN, Warszawa 1987, s. 25

${ }^{40}$ E. Domańska, Historia egzystencjalna, op. cit., s. 181.
} 